\title{
Components of nest provisioning behavior in solitary bees (Hymenoptera: Apoidea)*
}

\author{
John L. NEFF \\ Central Texas Melittological Institute, 7307 Running Rope, Austin, Texas 78731, USA
}

Received 13 June 2007 - Revised 28 September 2007 - Accepted 1 October 2007

\begin{abstract}
The components of nest provisioning behavior (resources per cell, transport capacity, trip duration, trips per cell) are examined for a data set derived from the literature and various unpublished studies. While there is a trade-off between transport capacity and trips required per cell, the highest provisioning rates are achieved by bees carrying very large pollen loads at intermediate trip durations. Most solitary bees appear to be either egg or resource limited, so sustained provisioning rates over one cell per day are unusual.
\end{abstract}

Provisioning rate / body size / transport capacity / solitary bees / trip duration

\section{INTRODUCTION}

There is a vast literature on the foraging tactics of bees: what kinds of flowers to visit, how long to spend on a flower, how many flowers in an inflorescence to visit, when to turn, and so forth. Much of this work is done within a framework of whether a forager should maximize harvesting rate or foraging efficiency (harvesting rate adjusted for foraging costs). Virtually none of this research is done with any consideration of the possible constraints on the actual provisioning patterns of solitary bees. Much of the theory on bee foraging behavior is based on the activities of social bees, principally Apis and Bombus, but their life histories may not be appropriate models for the 14000 plus species of solitary bees. Questions that need to be addressed but that have received little attention include the following. What are the implications of egg limitation? What are the implications if provisioning is limited to one cell per day (or fewer) regardless of resource availability? Are the possible

Corresponding author: J.L. Neff, jlnatctmi@yahoo.com

* Manuscript editor: Bryan Danforth tradeoffs between provisioning one large cell or two small cells direct, indirect, or nonexistent? Are provisioning rates related to body size?

Provisioning rate is a general term and can simply refer to the rate (mass per unit time) at which foragers bring various food items (pollen, nectar, oils, carrion, or whatever) to their nests. Several factors are involved in nest provisioning rates: resources needed per cell, transport capacity, trips needed to complete a cell, and cells completed per day. Such a concept applies to all bees, but for eusocial taxa it is only indirectly related to offspring production because of the high costs of colony maintenance, the prevalence of food storage, and in Apis, the unknown costs of the production of glandular food. Here I focus on solitary bees and use provisioning rate in a more restricted sense: the amount of resources collected per hour as a proportion of forager body weight. In a few cases, I have included data from the social halictines since, unlike the social apids, all are mass provisioners and their nest provisioning behavior is typically very similar to that of solitary bees. Additionally, some solitary bees do include significant amounts of glandular materials in their nest provisions (Norden 
et al., 1980; Batra and Norden, 1996) but as we currently have no estimates of the costs of these materials, they are not considered here.

The amount of time to provision a cell is determined by a number of parameters. These include the amount of resources necessary to produce an offspring of a given size and the amount of resources that can be transported per foraging trip (the transport capacity). Ideally, the amount of required resources divided by the transport capacity will yield the required number of foraging trips to provision a cell. Finally, foraging trip duration (plus the time required to unload pollen in the nest) times the number of foraging trips will yield provisioning time per cell. All of these factors are variables, so in many cases, determining the amount of time to provision a cell may be considerably more complicated than is suggested by the simple scheme indicated above. For bees provisioning more than one cell per day, additional factors to consider are empty cell availability and egg availability.

This review examines each of these components to see if there are general patterns across solitary bee taxa or even if there are enough data to discern such patterns. Each factor is discussed in turn using published literature and data I have collected over the last 30 years.

\section{MATERIALS AND METHODS}

A database on the various components of provisioning rates for 92 bee species was compiled from the literature and various unpublished studies (both my own and that of other workers) and is available from the author. For data gleaned from the published literature a variety of methods were used. Methods of cited authors are given when discussing their results. For many species, the data are quite fragmentary and heterogeneous. Body weights are variously reported as fresh weight, dry weight, or omitted entirely. For species where weights were not provided, body dry weights $\left(\mathrm{BM}_{d r y}\right)$ were estimated by using the strong correlation between trans-tegular distance (TTD) and dry body mass $\left(\mathrm{BM}_{d r y}=2.70+\mathrm{TTD}^{2.94}\right.$, Danforth, 1989b). Studies in which female weights were not given and specimens were not available for measurement were excluded.
Similarly, pollen loads and provision masses have been reported sometimes as fresh weights, sometimes as dry weights, sometimes both, and sometimes as numbers of pollen grains. Studies in which it could not be determined if wet or dry weights were reported were excluded. Because of the obvious problems of variable moisture levels, comparisons are made only on a fresh weight: fresh weight or dry weight: dry weight basis. Pollen counts may, with proper precautions, allow an accurate estimation of the number of trips required per cell or the number of flowers a bee may have to visit to complete a load or provision a cell, but simple pollen grain numbers are not useful for comparisons between species. In a number of cases, data on pollen loads were extracted from graphs when not given explicitly in the text.

Conversion ratios were calculated by dividing average provision dry mass by average bee dry mass. Since many species have strong sexual size dimorphisms, I made an attempt to associate sexes with appropriate provision masses when I could determine them from position in the nest or bimodal distributions of provision masses. When the distribution of pollen masses was not bimodal, despite strong adult size dimorphism, I determined an average bee weight from the average of male and females weights adjusted by the sex ratio, if known. If the sex ratio was not known, I employed the conservative, but sometimes erroneous, assumption of the sex ratio being inversely proportional to the investment ratio.

\section{RESULTS}

\subsection{Resources per cell}

Comparisons of the amounts of resources required to produce an offspring are complicated by many factors, the most obvious of which is that one is dealing with mixed currencies. Provision masses of solitary bees typically consist of mixtures of pollen and sugar (from nectar), the proportions or which are usually unknown. In a few cases, they may also contain floral oils (with or without added sugar) (Vinson and Frankie, 1999; Camilo, 2005; and pers. obs.), or glandular substances added by the female (Norden et al., 1980). One simple, and perhaps simpleminded, approach is to ignore these differences and calculate conversion ratios of the provision dry 
mass divided by the bee dry mass. While far from ideal, this approach yields values permitting comparisons between species. Among examples I have found, dry weight ratios ranged from $2.75: 1$ to $8.33: 1$ and averaged $4.66: 1$ while fresh weight ratios ranged from 1.90:1 to $3.67: 1$ and averaged 2.87:1 (Tab. I). I have excluded the values from the pioneering work of Strickler (1979) since much of the mass of the provisions was apparently lost during washing. Provision masses of Hoplitis anthocopoides, which were washed to remove sugars in order to determine the mass of collected pollen, had only $22 \%$ of the mass of intact provision masses (Strickler, 1979, 1982). This loss is considerably greater than what would be expected if only sugars were removed. The high conversion ratios seen in some megachilids are due, at least in part, to their considerable investment in cocoon construction. For males, cocoons average $49.3 \%$ of adult body weight in Osmia cornuta (Bosch and Vicens, 2002) and $47.5 \%$ in Osmia ribifloris (Neff, unpubl. data). Investment in female cocoons (as a\% of adult dry weight) is lower in these species $(39.9 \%$ and $40.9 \%$ respectively). Overall, these conversion ratios suggest that a bee must collect 4-5 times its body dry weight to provision a female cell, or 2-3 times its fresh weight.

The amount of nectar in the provisions varies widely among taxa. At one extreme, most diphaglossine colletids have essentially liquid (presumably nectar) provisions with only a suspension of pollen (Rozen, 1984). At the other extreme, provision masses of some Emphorini, like Diadasia, are nearly dry, with very little added nectar (Neff and Simpson, 1992). Apparently solid provision masses may, however, contain large amounts of nectar. A provision mass of Megachile rotundata was reported to contain $38 \mathrm{mg}$ of pollen and $63 \mathrm{mg}$ of nectar (fresh weight) (Klostermeyer et al., 1973). Although neither the pollen dry weight nor the nectar concentration was given, reasonable values for these variables suggest that sugar and pollen could easily be equal contributors to the provision mass dry weight.

A major unknown factor is the nutritional value of different pollens for different bees. Different pollens are known to vary widely in many factors (Todd and Bretherick, 1942; Baker and Baker, 1979; Roulston and Cane, 2000). Pollen protein content is commonly considered the most important factor for bees (Roulston and Cane, 2000 Roulston et al., 2000). The protein content of pollens collected by bees ranges from 12 to $61 \%$ (Roulston et al., 2000). One might expect that bees collecting high protein pollen might require less pollen to produce offspring of a given mass than those collecting low protein pollen but there are few data on this point. In a feeding experiment using different pollens with different protein contents collected by Lasioglossum zephyrum, a mass provisioning, polylectic, social halictine, offspring mass increased with increasing protein content in a linear manner (Roulston and Cane, 2002). This result strongly suggests that for this species, smaller amounts of high protein pollen are needed to produce an offspring of a given size relative to the required amounts pollens of lower pollen content. However, offspring mass varied because the size of the provision masses did not vary with pollen type, indicating the foragers were not able to recognize protein content differences.

Calliopsis persimilis restricts its pollen collection to Physalis (Solanaceae) (Danforth, 1990). Although the protein content of Physalis pollen is unknown, the Solanaceae are characterized by high pollen protein content (34.1-54.9\%, Roulston et al., 2000). As might be expected if usage of high protein content pollen reduced the amount of pollen necessary to produce viable offspring, C. persimilis has a conversion ratio of $3.12: 1$, near the lowest in my small sample (Tab. I). While low, this conversion ratio is not much lower than that of other panurgines such as Perdita difficilis (3.27:1) or Pseudopanurgus aethiops (3.35:1), bees with floral hosts that have moderate to low pollen protein content (Fabaceae: Prosopis, 39\%, and Asteraceae: $11.7 \%-34.3 \%$, respectively (Roulston et al., 2000)), and it is higher than that of Panurginus polytrichus $(2.75: 1)$, a polylectic species. The weak link between pollen protein content and conversion ratios (Tab. I) may simply reflect the mixed quality of the data, but it could also indicate that factors other than protein content 
Table I. Bee provision to female adult weight conversion ratios (CR).

\begin{tabular}{|c|c|c|c|c|c|}
\hline Species & Family $^{2}$ & $\begin{array}{c}\text { CR } \\
\text { (dry) }\end{array}$ & $\begin{array}{l}\text { CR } \\
\text { (wet) }\end{array}$ & $\begin{array}{l}\text { Floral hosts and } \\
\text { pollen } \% \text { protein }{ }^{1}\end{array}$ & References \\
\hline$\overline{\text { Panurginus polytrichus }}$ & And & $2.75: 1$ & & polylectic & Neff, 2003 \\
\hline Calliopsis persimilis & And & $3.12: 1$ & & Asteraceae: $45.5 \%$ & Danforth, 1990 \\
\hline Perdita difficilis & And & $3.27: 1$ & & $\begin{array}{l}\text { Fabaceae: Prosopis } \\
39 \%\end{array}$ & $\begin{array}{l}\text { Danforth, } \\
\text { unpublished }\end{array}$ \\
\hline Pseudopanurgus aethiops & And & $3.35: 1$ & & Asteraceae & Neff, unpublished \\
\hline Perdita luciae & And & $3.57: 1$ & & $\begin{array}{l}\text { Fabaceae: } \\
\text { Prosopis 39\% }\end{array}$ & $\begin{array}{l}\text { Danforth, } \\
\text { unpublished }\end{array}$ \\
\hline Macrotera portalis & And & $3.84: 1$ & & $\begin{array}{l}\text { Malvaceae: } \\
\text { Sphaeralcea: } 29.4 \%\end{array}$ & Danforth, 1991 \\
\hline Macrotera texana & And & $3.89: 1$ & & Cactaceae: $25.1 \%$ & $\begin{array}{l}\text { Neff and Danforth, } \\
1991 \text {, }\end{array}$ \\
\hline Perdita punctosignota & And & 4.00:1 & & $\begin{array}{l}\text { Fabaceae: } \\
\text { Prosopis 39\% }\end{array}$ & Danforth unpublished \\
\hline Hesperapis sp. A & Mel & 4.66:1 & 2.01 & Asteraceae: $45.5 \%$ & Neff, unpublished \\
\hline Lasioglossum figueresi ${ }^{3}$ & Hal & $4.85: 1$ & & polylectic & Wcislo et al., 1993 \\
\hline Diadasia afflicta & Api & $5.01: 1$ & & Malvaceae: $21.6 \%$ & $\begin{array}{l}\text { Neff et al., } 1982 \\
\text { and unpublished }\end{array}$ \\
\hline Hoplitis anthocopoides & Meg & $5.09: 1$ & & Boraginaceae & Strickler, 1979, 1982 \\
\hline Halictus ligatus $^{3}$ & Hal & $5.5: 1$ & & polylectic & $\begin{array}{l}\text { Boomsma and } \\
\text { Eickwort, } 1993\end{array}$ \\
\hline Osmia cornuta & Meg & $5.89: 1$ & 3.67 & polylectic & $\begin{array}{l}\text { Bosch and Vicens, } \\
2002\end{array}$ \\
\hline Diadasia australis & Api & $5.89: 1$ & 3.36 & Cactaceae: $25.1 \%$ & Neff, unpublished \\
\hline Osmia nigrifrons & Meg & $6.21: 1$ & & polylectic & Rust et al., 1974 \\
\hline Osmia cornifrons & Meg & $8.33: 1$ & & polylectic & Maeta, unpublished \\
\hline Ceratina calcarata & Api & & 2.87 & polylectic & Johnson, 1988 \\
\hline Andrena agilissima & And & & $1.90^{4}$ & & $\begin{array}{l}\text { Giovanetti \& Lasso, } \\
2005\end{array}$ \\
\hline Megachile rotundata & Meg & & $2.72^{4}$ & polylectic & $\begin{array}{l}\text { Klostermeyer et al., } \\
1973\end{array}$ \\
\hline Osmia lignaria & Meg & & 3.59 & polylectic & Levin, 1966 \\
\hline Osmia lignaria & Meg & & 3.07 & polylectic & $\begin{array}{l}\text { Philips \& } \\
\text { Klostermeyer, } 1978\end{array}$ \\
\hline Ptilothrix bombiformis & Api & & 2.67 & Malvaceae: $21.6 \%$ & Rust, 1980 \\
\hline
\end{tabular}

${ }^{1}$ Pollen protein $\%$ from Roulston et al., 2001.

${ }^{2}$ And $=$ Andrenidae, Api $=$ Apidae, $\mathrm{Hal}=$ Halictidae, $\mathrm{Meg}=$ Megachilidae, Mel $=$ Melittidae.

${ }^{3}=$ social.

${ }^{4}=$ combined pollen ball but female adult weight only so underestimate likely.

are of greater importance in determining provision amounts.

A further complication in assessing resources needed per cell may be differential costs of producing a male or a female. In bees, males are typically smaller and lighter than females and thus it should be cheaper to produce males than females, but exactly how much more cheaply is open to question. Several studies indicate that on a per unit mass basis, more provisions are required to produce a male than a female (Danforth, 1990). A variety of explanations have been proposed for this cost difference (Trivers and Hare, 1976; Boomsma, 1989). However, sex specific cost differences do not appear to be universal among bees as 
they were not detected in studies of Osmia cornuta (Bosch and Vicens, 2002) or Megachile rotundata (Klostermeyer et al., 1973).

\subsection{Transport capacity}

Transport capacity, the amount of provisions that can be carried per foraging trip, varies widely among bee species. Pollen may be transported internally or externally. Internal pollen transport is the exclusive mode in the Hylaeinae and Euryglossinae and probably is extensive in groups with reduced scopal structures like the Ceratinini,Xeromelissinae, or the African Colletes species with greatly reduced scopae (Kuhlmann, 2006). Unfortunately, nothing is known about the pollen transport capacities of bees with internal pollen transport.

External pollen transport may be either dry (all Halictidae, Colletidae, Megachilidae, and many Apidae) or agglutinated with nectar, or sometimes floral oil (nearly all Panurginae and Melittidae, and some Eucerini, Exomalopsini, as well as nearly all the oil-collecting and corbiculate apids). The relative advantages of dry versus agglutinated pollen transport are unclear. Available data suggest that agglutination allows for larger pollen loads as a proportion of body weight relative to dry transport (Tab. II). Unfortunately the data are biased with agglutinators being represented by smaller bees (body dry weight less than $20 \mathrm{mg}$ ) while the dry carriers are all larger bees (body dry weight greater than $20 \mathrm{mg}$ ) so meaningful comparisons are difficult. There is also an indication that dry pollen transport may allow for more rapid pollen loading than agglutination since it omits the step of nectar addition. The fastest averages for provisioning trip duration (less than 3 minutes) are found in dry carriers like Lasioglossum lusorium (Bohart and Youssef, 1976) and Diadasia afflicta (Neff, unpubl. data).

On a dry weight basis, reported pollen loads vary from $21.7 \%$ to $131 \%$ of forager body weight (Tab. II) while for fresh weights (with a slightly different data set) the range is $4.5 \%$ to $48.8 \%$. The lowest reported average fresh weight pollen load $(4.5 \%)$ is for
Megachile rotundata. The average maximal provision load for this species is $23 \%$ of body fresh weight and the average provision load is $12-13 \%$ of body fresh weight but in both cases, most of the provision load is nectar (Klostermeyer et al., 1973).

Among species, larger taxa tend to carry larger pollen loads (Fig. 1) but they do not carry proportionally larger loads (Fig. 2). If anything, we would expect pollen loads as a proportion of body weight to decrease with increasing body weight since wing loading decreases with increasing body size in bees (Danforth, 1989b; Bullock, 1999). Pollen load as a percentage of body weight is significantly negatively correlated with body weight for dry $\left(\mathrm{R}^{2}=0.377, P=0.002\right)$ but not fresh weight $\left(\mathrm{R}^{2}=0.11, P=0.105\right)$. However, the validity of the dry weight correlation is suspect due to uneven sampling. The dry weight data set consists of either relatively small $(<20 \mathrm{mg})$ agglutinating species or larger $(>20 \mathrm{mg}$ ) dry carriers (Tab. II). When the data sets are analyzed separately for dry carriers or agglutinators, no significant correlations between body weight and percent pollen load as a $\%$ of body weight are found on either a dry or wet weight basis $(P$ all $>0.5)$.

Although we would expect that within species, larger individuals would carry larger provision loads than smaller individuals, studies commonly fail to find such a correlation (Neff and Simpson, 1992; Stone, 1994; Tomkins et al., 2001; Giovanetti and Lasso, 2005). In some cases the absence of a correlation may reflect little more than sampling error and small sample sizes, but it also has been noted in studies with large sample sizes (Stone, 1994; Giovanetti and Lasso, 2005). Bees probably have difficulty in determining exactly what constitutes a full provision load. In studies where weights were experimentally added to the bodies of foragers, the bees did not compensate by reducing their pollen loads (Tompkins et al., 2001). Bees with external pollen loads are presumably measuring the volume rather than the weight, of their scopal loads but the degree of accuracy with which they accomplish this is unknown.

Transport capacity may not be constant through the life of a bee. Sugiura and Maeta 


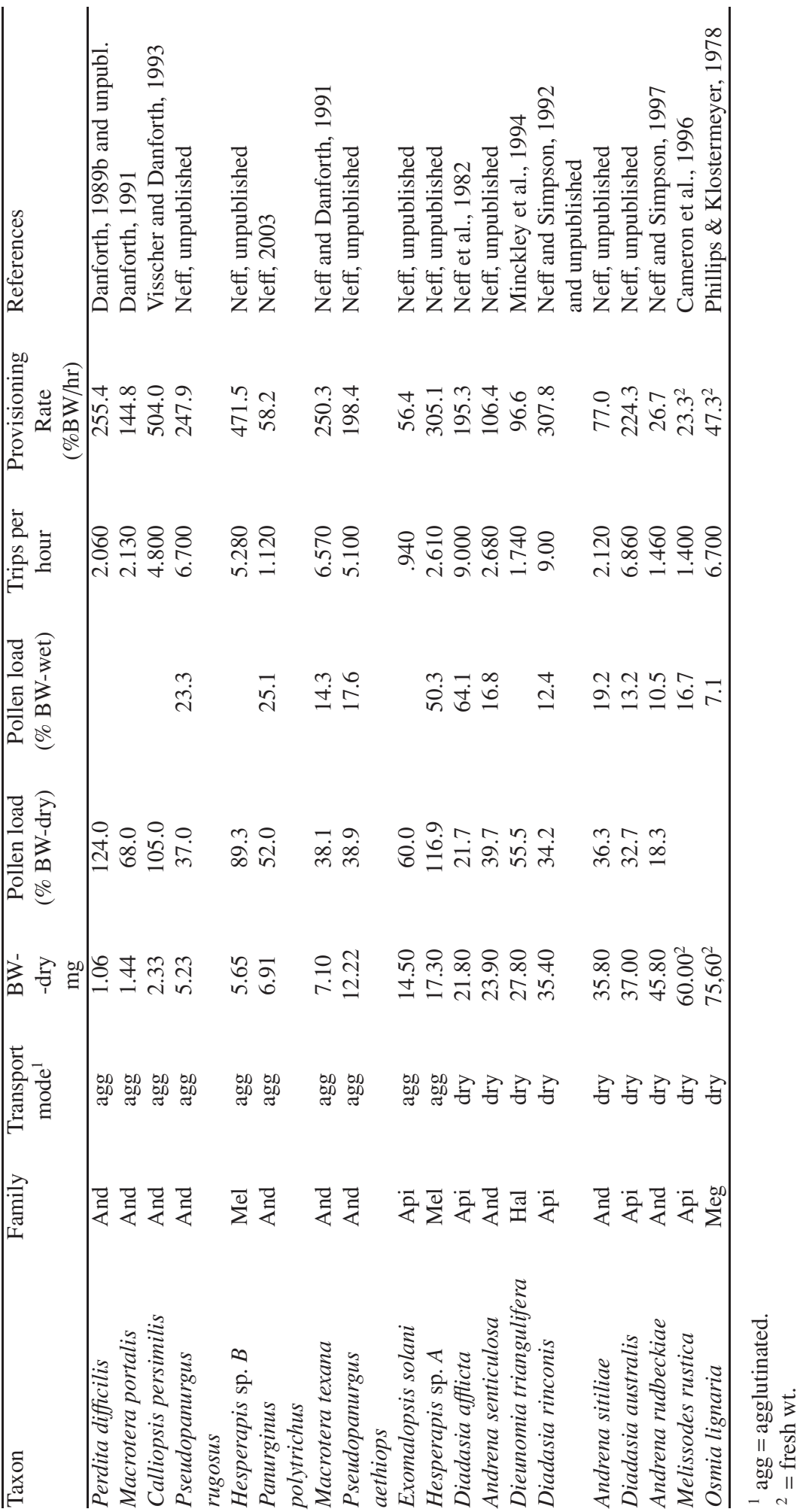




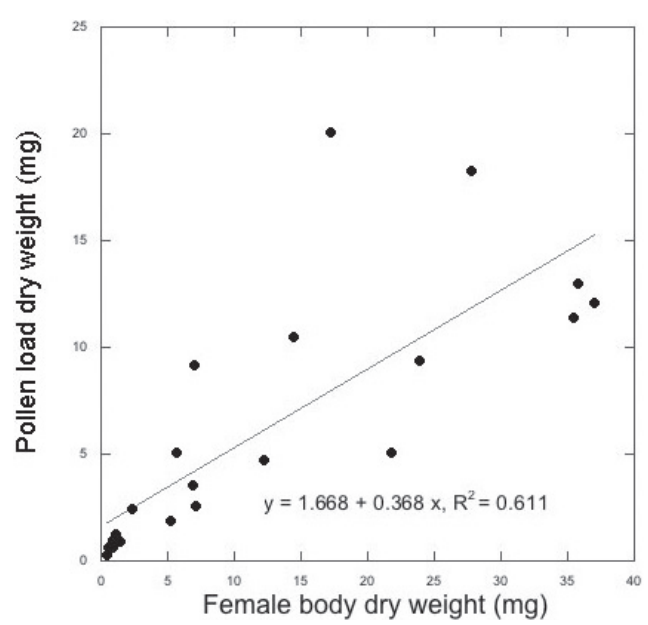

Figure 1. Relationship between female body weight and pollen load (dry weights), $\mathrm{n}=22$.

(1989) found that the abdominal scopae of older, "senile" females of Osmia cornifrons were conspicuously worn compared to those of fresh females, and they argued this resulted in reduced pollen carrying ability. As a result, older females required more provisioning trips per cell than younger females

\subsection{Trips per cell}

Among solitary bees, the number of foraging trips required to provision a cell varies from two (in several Perdita species, (Danforth, 1989a)) to more than 40 (in Megachile pugnata, (Frohlich and Parker, 1983)). Although it needs confirmation, queens of Halictus lanei, who are up to eight times the mass of a small worker, may provision a worker cell with a single foraging trip (Janjic and Packer, 2001).

While there are many reports in the literature on the number of trips per cell, it is not always clear if some authors are distinguishing the number of trips per day from number of trips per cell. The number of trips per cell is most accurately determined when activities within the nest, including oviposition, can be directly observed, as in systems with transparent sided observation nests (Danforth, 1991 and references within) or when activities of

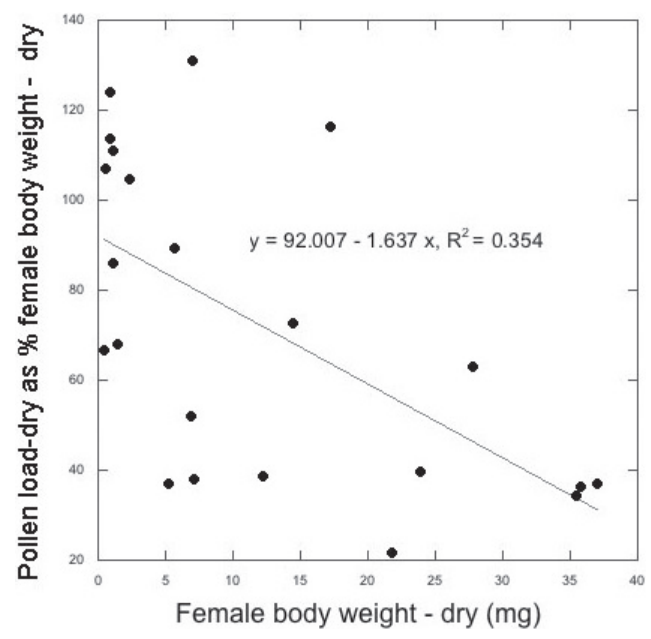

Figure 2. Relationship between female body weight and pollen load as a \% of body weight (dry weights), $\mathrm{n}=22$.

trap-nesting species can be monitored within the nest with the aid of illuminating devices such as an opthalmoscope. Nests with automated timing and weighing systems also can yield accurate measures of the number of trips per cell.

A variety of indirect methods have been used to estimate the number of trips required per cell. One is simply to divide the weight of the finished provision mass by the weight of an individual pollen load (Witt, 1992; Giovanetti and Lasso, 2005). Simple in concept, this method may significantly overestimate the number of trips per cell when only scopal loads are measured but there is a significant weight contribution from sugar (or pollen) carried in the crop. This method may also be misleading if there is significant diel, seasonal or inter-annual variation in pollen load size (Minckley et al., 1994) or the sizes of pollen loads vary systematically through a provisioning series (Klostermeyer et al., 1973). Determining the dry weight of an individual pollen load usually requires sacrificing foragers, a major drawback when dealing with small populations. Non-destructive methods have been used in several studies (Stone, 1994; Giovanetti and Lasso, 2005), allowing the collection of many measurements of fresh pollen 
and nectar load weights linked to forager body size without sacrificing foragers.

Alternatively, some researchers report the number of pollen grains in an average provision mass, and divide this by the average number of grains per pollen load (Mohamed, 1973; Witt, 1992; Visscher and Danforth, 1993; Minckley et al., 1994; Cane et al., 1996; Bischoff et al., 2003). Like the previous method, this technique is subject to all the caveats about variation in pollen loads. This method should give a reasonable estimate of the number of pollen trips required per cell as long as only one pollen type is collected (or at least pollens of the same size). The utility of this method will be greatly reduced when the collected pollens vary significantly in size. Simple counts may significantly under- or overestimate the number of pollen trips required per cell unless the proportions of different pollen are the same in the provision masses and individual pollen loads or appropriate corrections are made for pollen size. Counting grains may also overestimate the number of required trips if there are significant, but unmeasured, amounts of pollen carried in the crop as in some Colletes spp. (Neff, pers. obs.). Finally, the method ignores any nectar-only provisioning trips, a common feature in megachilid and some apid provisioning series. Consequently, without outside observations, counting pollen grains cannot give a complete accounting of the number of foraging trips per cell.

Behavioral criteria, such as an extended series of pollen collecting trips followed by a lengthy period in the nest, sometimes accompanied by non-pollen foraging trips or expulsion of soil from the nest, are commonly used to indicate the completion of a provisioning series (Parker et al., 1981; Ordway, 1984; Danforth, 1990; Neff and Simpson, 1992; Bischoff et al., 2003). The interval between continuous pollen provisioning flights is then taken to include time for oviposition, cell closure, and construction of the next cell. While this is almost certainly true in some cases (Danforth, 1990), it now appears questionable in others. Neff and Simpson (1992) claimed that Diadasia rinconis, a cactus specialist, provisioned up to 3 cells per day, each requiring an average of 10.6 foraging trips. Intact provision masses were not obtained but the average of 10.6 pollen trips times 13.0 Fig. per trip was estimated to yield an average pollen mass of $137.8 \mathrm{mg}$. Since females averaged $104.7 \mathrm{mg}$, this amount indicated a fresh weight conversion ratio of $1.32: 1$, a value that seemed plausible at the time.

I later studied the provisioning behavior of Diadasia australis. This species is very similar in size and appearance to D. rinconis (Tab. II), is also a cactus specialist, and has been shown to be the sister species of $D$. rinconis (Sipes and Wolf, 2001). The provisioning behavior of $D$. australis is also virtually identical to that of $D$. rinconis. Like $D$. rinconis, it appears to provision up to three cells per day, with series of 10.4 consecutive pollen trips and intervals averaging $60 \mathrm{~min}$ between pollen series. Also similar to $D$. rinconis, its average pollen load is $11.6 \%$ of its body fresh weight predicting a completed wet pollen mass of $144.6 \mathrm{mg}$. However, when actual pollen balls were measured, some problems were obvious. Pollen masses of Diadasia australis averaged $351.8 \mathrm{mg}$ (wet) or $217.9 \mathrm{mg}$ dry, far to heavy to be produced in only 10 trips with the measured pollen loads. Similarly, excavations of completed $D$. australis nests with known periods of activity had only half the number cells predicted from cell completion rates assuming 10 trips per cell (Neff, unpublished). It is not clear exactly what females of D. australis are doing in the hour or more long intervals between foraging series, but apparently often it is not ovipositing and closing a cell. For D. australis, D. rinconis, and probably the closely related $D$. opuntiae (Ordway, 1984) these intervals, and attendant nectaronly flights, do not appear to be reliable indicators of the completion of provisioning of a cell. Although it is possible we simply have grossly underestimated pollen loads, it seems more likely that these bees actually require around 20 trips to provision a cell and provision no more than 1.5 cells per day. It is not clear if this pattern of interrupted provisioning is an odd quirk of this clade of cactus-feeding Diadasia, or is more widespread among bees, but it does suggest that caution should be used 
when using uncorroborated behavioral indicators of the completion of cell provisioning.

Because many bee species show strong inter- or sometimes intra-sex size dimorphism we expect provisions per cell to be more or less proportional to offspring size (more or less since males may [Danforth, 1990], or may not [Bosch and Vicens, 2002] be more expensive to produce than females on a per unit mass basis). Concomitantly, bimodal distributions of trips per cell would be expected for species with strong size dimorphisms. Most authors have simply ignored the problem, perhaps due to the absence or paucity of data appropriate to address the question (Minckley et al., 1994). However, in Amegilla dawsoni (Alcock, 1999) Calliopsis pugionis (Visscher and Danforth, 1993), and Hesperapis sp. A, (Neff, unpubl.), the larger sex (or morph) is twice the mass of the smaller, yet the modal numbers of trips per cell are 3 and 4 for Calliopsis pugionis, 2 and 3 for Hesperapis sp. A, and no clear mode for Amegilla dawsoni, despite a range of 6 to 26 trips per cell. Apparently these bees are adjusting pollen load size in a currently poorly understood manner.

Overall, no correlation was found between body weight and the number of trips per cell for the large, dry weight data set $\left(n=67, R^{2}=\right.$ $0.007, P=0.5066$ ). Within families, a significant positive correlation was found between body dry weight and number of trips per cell only for the Andrenidae, and within it, only for the agglutinating Panurginae $(P=0.488$, $\left.\mathrm{R}^{2}=0.026\right)$. No such correlation was evident for the Apidae, Megachilidae or Halictidae while sample sizes were too small for analysis of the Colletidae and Melittidae. A significant positive correlation between body weight and number of trips per cell was found for the smaller fresh weight data set $\left(\mathrm{R}^{2}=0.323, P=\right.$ 0.0090 ) but again this was largely due to the contribution of the Andrenidae $\left(\mathrm{R}^{2}=0.695\right.$, $P=0.0008)$. The positive correlation was nearly significant in the Apidae $\left(\mathrm{R}^{2}=0.761\right.$, $P=0.0536)$ while sample sizes were too small (or nonexistent) for separate analyses of the remaining families.

As we might expect, there is a tradeoff between pollen load size and number of trips per cell when controlling for body size. Pollen

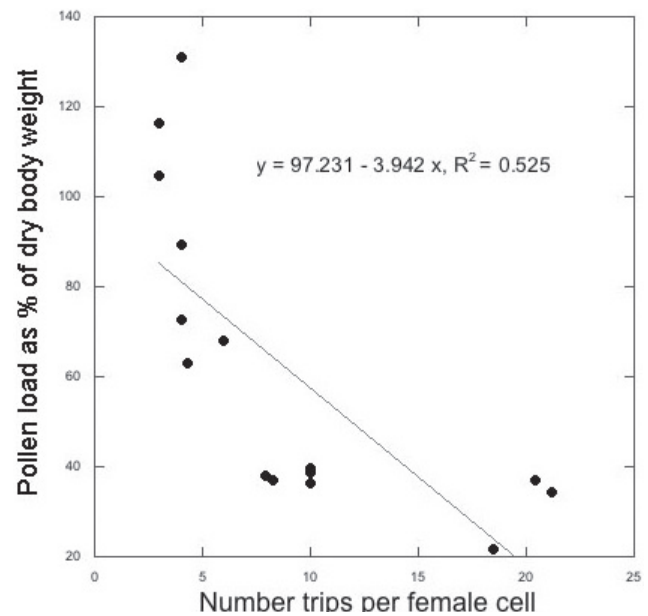

Figure 3. Relationship between number of trips per cell and pollen load as \% of body weight (dry weights), $\mathrm{n}=17$.

load as a proportion of body weight is negatively correlated with the number of trips per cell on both a fresh $\left(\mathrm{R}^{2}=0.462, P=0.0014\right)$ and dry $\left(\mathrm{R}^{2}=0.548, P=0.0014\right)$ basis (Fig. 3). For bees of a given size class, species with larger pollen loads will require fewer trips per cell than species with smaller average pollen loads.

\subsection{Trip duration}

Like all other aspects of provisioning, foraging trip duration varies widely. Some species regularly complete a pollen collecting trip in two minutes or less (e.g., Lasioglossum lusorium, [as Evylaeus galpinsiae], Bohart and Youssef, 1976) while others, like some Andrena species, regularly take an hour or more per trip (Gebhardt and Röhr, 1987) or even, like Eulaema meriana, nearly two hours (Cameron and Ramirez, 2001). The limited data available suggest that for interspecific comparisons, bee size does not matter in determining trip duration. Number of trips per hour, a measure of trip duration, is not correlated with body weight on either a dry $\left(\mathrm{R}^{2}=\right.$ $0.004, P=0.821)$ or fresh weight basis $\left(\mathrm{R}^{2}=\right.$ $0.007, P=0.825)$. More surprisingly, since one might expect bees with larger proportional pollen loads to take longer to complete a 
pollen trip than bees whose loads are a smaller proportion of their body weight, there is no significant correlation between trips/hour and pollen load as a percentage of body weight on either a fresh $\left(\mathrm{R}^{2}=0.009, P=0.811\right)$ or dry weight basis $\left(\mathrm{R}^{2}=0.107, P=0.201\right)$. Some bees fit the predicted pattern. The Diadasia species gather relatively small pollen loads during relatively short trips while Perdita difficilis and Hesperapis sp. A gather large loads on relatively on long trips (Tab. II). Unfortunately for the correlation, other species like Calliopsis persimilis gather large loads relatively quickly, and still others, like Andrena rudbeckiae and Panurginus polytrichus, gather relatively small loads rather slowly (Tab. II). Apparently other, often unmeasured, factors like resource availability (Minckley et al., 1994) or harvesting skill (Strickler, 1979) play important, perhaps overriding, roles in determining pollen trip duration.

There have been a few experimental studies of the effects of resource levels on provisioning rates in solitary bees. Kim (1999) found that doubling resource availability increased cell production per day of Megachile apicalis by $33 \%$ (from 1.2 to 1.6 cells per day) and amount provisioned per day by $32 \%$ (from 190 to $250 \mathrm{mg}$ ). Higher resource levels also led to a higher proportion of females among progeny $(50 \%$ vs. $30 \%)$ and a higher investment in females $(60 \%$ vs. $35 \%)$. In a similar cage study, Goodell (2003) found that female Osmia pumila in "rich" treatments (floral resource availability approximately twice that of "sparse" treatments) produced 1.5 times as many cells as the bees in "sparse" treatments. Interestingly, resource availability had no significant effect on trip duration so it is not clear what was the mechanism leading to higher cell production in the "rich" treatments.

\subsection{Provisioning rates}

Provisioning rates can be defined as the amount of resources gathered per hour as a percentage of forager body weight. Provisioning rates are one way to compare the provisioning abilities of different species in the absence of, or as a complement to, information on trips per cell, number of cells completed per day, or time needed to provision a cell. As in all other components of provisioning behavior, these rates vary widely between species. At the high end, Calliopsis persimilis has a provisioning rate of $504 \%$ of its BM $_{\text {dry }}$ per hour (Tab. II). Although actual pollen loads are unavailable, individuals of Lasioglossum lusorium may exceed $1300 \% \mathrm{BM}_{\mathrm{dry}} / \mathrm{hr}$, assuming a conversion ratio $4: 1$ and a cell completion rate of 3.3 cells per hour during its brief foraging periods. At the low end, Andrena rudbeckiae has a rate of only $26.7 \% \mathrm{BM}_{\mathrm{dry}} / \mathrm{hr}$ (Tab. II).

Provisioning rates were not correlated with body weight on either a dry $\left(\mathrm{R}^{2}=0.184, P=\right.$ $0.0856)$ or fresh weight basis $\left(\mathrm{R}^{2}=0.022\right.$, $P=0.7027)$. Although the components of provisioning rates (trips per hour and pollen loads as a $\%$ of body weight) are not correlated with one another $\left(\mathrm{R}^{2}=0.107, P=0.2009\right)$, both trips per hour $\left(\mathrm{R}^{2}=0.269, P=0.0327\right)$ and pollen load as a \% of body mass $\left(\mathrm{R}^{2}=0.296\right.$, $P=0.0211)$ are positively correlated with provisioning rate. Since, the highest provisioning rates are achieved by bees with very large pollen loads but intermediate numbers of trips per hour, the fit between trips per hr and provisioning rate on a dry weight basis is significantly improved with polynomial regression $\left(\mathrm{R}^{2}=0.515, P=0.0063\right.$ ) (Fig. 4). Polynomial regression did not, however, improve the fit between provisioning rate trips per hour $\left(\mathrm{R}^{2}=0.297, P=0.085\right)$.

\subsection{Cells per day}

The maximum reported number of completed cells per day is nine by an individual of Osmia lignaria (Torchio, 1989). This is a surprisingly high number for a species usually requiring 35 trips for a female cell and 31 for a male (Phillips and Klostermeyer, 1978). This high rate was achieved under benign glasshouse conditions with optimal climate and essentially unlimited foraging and nest constructions materials near the nest. In another glasshouse study, a few females of $O$. lignaria averaged over three cells per day but the population average was 1.81 (Tepedino and Torchio, 1982). Under field 


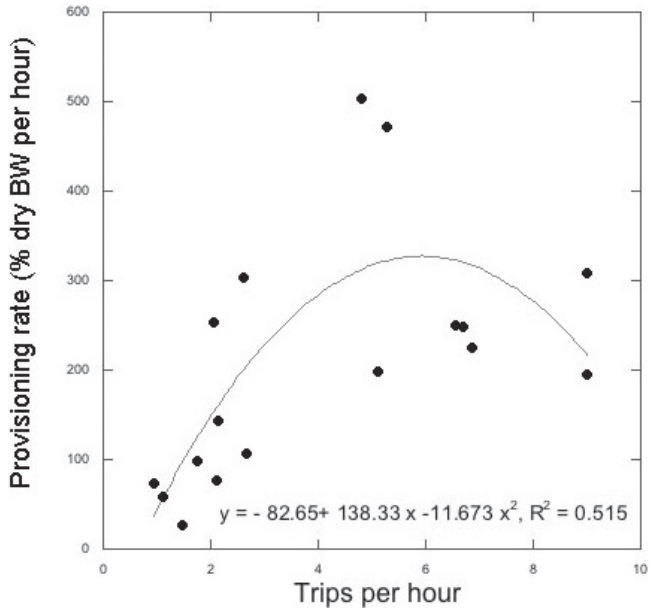

Figure 4. Relationship between number of trips per hour and provisioning rate, $\mathrm{n}=17$.

conditions, O. lignaria normally completes one, and occasionally two cells per day (Torchio, 1989). The highest reported daily cell completion rate under field conditions is six by Calliopsis persimilis, a bee which may average four cells per day, but perhaps far fewer (Danforth, 1990). A close runner-up is an undescribed, Asteraceae feeding Hesperapis sp. $A$ from Texas which provisions up to five cells per day, and averages 2.5 (Neff, pers. obs.). For short term rates, individuals of Lasioglossum lusorium were observed provisioning five cells in 90 minutes (or up to four in under two hours, the text is contradictory) (Bohart and Youssef, 1976). However, unlike the taxa mentioned above, all the cells were constructed before the start of provisioning and the female oviposited in no more than three of the provisioned cells immediately after she ceased foraging. The actual cell completion rate of $L$. lusorium may be closer to one cell per day since high provisioning days (seven or more trip days, interpreted as two or more cell days) are typically followed by one or two days of little or no provisioning. Similarly, nest excavations of Calliopsis persimilis suggested that the median number of cells completed per day may be just one, even though during observation periods no female was actually observed to provision only one cell per day (Danforth, 1990). As noted above, the reports of three cells per day for the cactus feeding Diadasia spp. (Ordway, 1984; Neff and Simpson, 1992) appear to be erroneous. Diadasia afflicta has also been observed to provision three cells per day (Neff, pers. obs) although it averages only one to two (Neff et al., 1982). Provisioning rates in this species may also need reinvestigation. Reports of bee species regularly completing two cells per day include Perdita coreopsidis (Danforth, 1989a), Megachile addenda (Cane et al., 1996), and Centris aenea (Aguiar and Gaglionne, 2003) but long term data on provisioning are not available for these species.

High cell completion rates (more than two cells per day) appear to be uncommon among solitary bees, and very high rates, more than three cells per day, very rare. In fact, it appears unlikely that any species of solitary bee actually averages three cells or more per day. The vast majority of solitary bees appear to provision one or fewer cells per day, some averaging a cell every four days or more (Gebhardt and Röhr, 1987; Giovanetti and Lasso, 2005). Besides inclement weather, the prime suspects for low cell completion rates are resource availability, reflected in low provisioning rates, and egg limitation (the lack of mature eggs for oviposition). Resource limitation is seen in the many species which, on average, simply do not harvest enough resources per day to provision a cell. In some cases, bees are able to provision a cell of the smaller sex (usually a male) in one day, but not a female (Neff and Simpson, 1997; Neff, 2003). Egg limitation also seems to be widespread among solitary bees. It is probably the major reason for cell completion rates of only one cell per day for species with high provisioning rates $(>200 \%$ BW-dry per hour) such as Macrotera texana (Neff and Danforth, 1991) or Pseudopanurgus rugosus (Neff, unpublished) (Tab. II). It is also the likely explanation for the common phenomenon of pollen foraging days followed by one or more days of nectar only foraging seen in many Andrena (Neff and Simpson, 1997; Bischoff et al., 2003) and other taxa (Minckley et al., 1994). While egg limitation seems to be widespread, it is far from obvious why this should be so since brood parasitic bees and 
social bees can ramp up egg production far beyond one egg per day.

\section{DISCUSSION}

Given the relatively small sample sizes and spotty taxonomic sampling, any conclusions from this study must be considered tentative at best. There probably are many advantages to larger size in bees in terms of provisioning behavior (greater foraging range, foraging at cooler temperatures, defense against predators or nest usurpers), but at least for the species sampled here, larger species do not carry proportionally larger pollen loads (if anything, they carry smaller) so any fitness advantages are not linked to transport capacity. Studies where provision masses were actually measured suggest a female typically needs to provision each cell with two to three times her body weight on a fresh weight basis or four to five times on a dry weight basis. Auxiliary costs, like for cocoon construction, can substantially increase these ratios. Estimates that suggest species provision cells with substantially less than these proportional amounts should be viewed with caution. There are some hints that bees that use higher quality pollen (higher protein content) may require less pollen to provision a cell than those using lower quality pollen (Danforth, 1990), but overall the data is ambiguous on this point.

The wide variety of provisioning strategies seen among different bee species, ranging from few trips with very large loads to many trips with relatively small loads, suggests there is no single optimal strategy for bees. The low load, many trip strategy implies that bees with that strategy will, on average, fly greater distances, but do less work per unit distance, than bees making few trips with large loads, the exact differences depending on distance to foraging areas and flight speed. The costs to the bees of the different strategies, in terms of wear and tear and their influence on future foraging ability, are unclear. Other factors probably play a role in determining provisioning strategies. The high numbers of trips per cell (often 30+) seen in some cavity renting megachilids appears to be due to low transport capability. Low transport capability in these bees may be a reflection of selection for reduced body cross-sectional area which should increase nest availability, assuming smaller cavities are more common than large ones. Nest defense against parasites might select for smaller loads if increasing foraging trip duration increases the possibility of successful parasite attack since other things being equal, smaller pollen loads should require less time to collect. However, if probability of attack was simply proportional to total time away from the nest, no clear strategy is indicated since there appear to be multiple pathways to maximizing provisioning rates.

The easiest conclusion to draw from a study of this sort is that we still know surprisingly little about the provisioning behavior of solitary bees. While the number of published reports is more extensive than that discussed here, they still cover only a tiny fraction of the world's bee diversity, with many major groups completely omitted. Much of the data are fragmentary or incomplete. In a given study, pollen loads may be given but not body weights or foraging trip durations; foraging trip durations may be included but not pollen loads; or provisions or pollen loads may be given only as fresh weights or number of pollen grains. These problems often make sense in the context of individual studies but they make cross species comparisons difficult. And of course, in many studies, sample sizes are extremely small. Obviously we need many more studies to fill in the taxonomic gaps of our knowledge of bee provisioning behavior. At a minimum, future studies need to include body, pollen load, and provision weight as dry weights to aid in comparisons. Studies of provisioning behavior need to be done on multiple consecutive days to get a better estimate on average number of trips or cells per day and the frequency of non-pollen foraging days as possible indicators of egg limitation. We also need more dissections of foragers at different stages in the provisioning process to check for egg availability. Of course, we need more experimental studies so we can move beyond the largely correlational nature of our current understanding of provisioning behavior. 
And finally, and probably the area of greatest difficulty, we need to be able to link provisioning patterns to resource availability. Although often given lip-service, we know very little about pollen harvesting effectiveness of bees on different flowers (rate of pollen collection per unit time), how those rates change as pollen availability changes, and whether the rates change in different ways for bees of different sizes. Floral resource availability needs to be measured as it changes through the day and through the season. This will require many measurements even in simple systems with oligolectic bees (Minckley et al., 1994), and will become much more difficult in complex systems with polylectic taxa since the number of taxa to be monitored may increase dramatically. Determining how to deal with the spatial distribution of floral resources can be difficult. Minckley et al. (1994) assumed that all appropriate flowers within the foraging area were equally likely to be used, even though they acknowledged distant plants were less likely to be utilized than closer ones. Determining what proportion of the available pollen is harvested by the focal bee species will also often be difficult. In real systems flowers are often visited by many different species whose pollen removal abilities may vary widely. In the absence of actual pollen removal data, Minckley et al. (1994) assumed that females of Dieunomia triangulifera harvested $32 \%$ of the available $\mathrm{He}$ lianthus pollen since they constituted $32 \%$ of the pollen collecting female bees at Helianthus flowers. While simplifying assumptions such as these are understandable in a pioneering study, more reasonable estimates will be necessary as we attempt more refined estimates of bee-flower relationships. Until we have a better understanding of the relationship between resource availability and provisioning behavior for more systems, we cannot say we know all that much about the provisioning behavior of bees.

\section{ACKNOWLEDGEMENTS}

I thank Bryan Danforth, Cornell University, who generously donated unpublished observations on bee body weights, pollen loads and provision weights, and Beryl Simpson, The University of Texas at Austin, Bill Wcislo, Smithsonian Tropical Research Institute, and an anonymous reviewer who made many useful comments on an earlier draft of the manuscript.

Éléments du comportement d'approvisionnement du nid chez les abeilles solitaires (Hymenoptera : Apoidea).

abeille solitaire / comportement d'approvisionnement / taille corporelle / capacité de transport / durée du trajet / article de synthèse

Zusammenfassung - Bestandteile des Nestversorgungsverhaltens bei Solitärbienen. Obwohl die meisten Bienen die überwiegende Zeit ihres Lebens mit der Versorgung von Brutzellen verbringen, gibt es bisher wenige Untersuchungen darüber, welche Rolle die verschiedenen Bestandteile des Versorgungsverhaltens bei der Fertigstellung der Brutzellen spielen. Die Bestandteile des Nestversorgungsverhaltens (Vorrat pro Zelle, Transportkapazität, Ausflugsdauer, Anzahl Ausflüge pro Zelle) wurden aus Literaturdaten sowie verschiedenen nicht veröffentlichten Studien zusammengetragen. Die Konversionsraten (Verhältnis von Versorgungsgewicht zum Gewicht der adulten Nachkommen) variieren erheblich zwischen den verschiedenen Taxa. Die Raten für die Trockengewichte reichen von 2,75:1 bis 8,33:1 (Mittelwert 4,66:1) während die Raten für Frischgewichte von 1,90:1 bis 3,76:1 reichen (Mittelwert 2,78). Die Nektarmenge, die zur Vorratsmasse hinzu gegeben wird, kann beträchtlich sein, wurde aber bisher kaum quantifiziert.

Die Pollentransportkapazität variiert von 21,7\% bis $131 \%$ des Körpergewichtes der Sammlerin auf der Basis des Trockengewichtes bzw. 4,5\% bis $48,8 \%$ auf der Basis des Frischgewichtes. Bei den verschiedenen Bienenarten transportieren große Arten bezogen auf das Trockengewicht tendenziell größere Pollenmengen. Berechnet als Prozentsatz des Körpergewichtes ist die Pollenmenge allerdings negativ mit dem Körpergewicht korreliert $\left(\mathrm{R}^{2}=\right.$ $0,377, P=0,002)$. Innerhalb der Arten sind Körpergewichte und die entsprechenden Pollenladungen häufig nicht korreliert.

Die Anzahl an Sammelausflügen, die für die Versorgung einer Zelle notwendig sind, reichen von zwei (eventuell einem) bis zu mehr als 40. Die Pollenladung als Anteil am Körpergewicht ist negativ korreliert mit der Anzahl an Ausflügen pro Zelle, sowohl auf der Basis von Frischgewicht $\left(\mathrm{R}^{2}=0,462\right.$, $P=0,0014)$ als auch Trockengewicht $\left(\mathrm{R}^{2}=0,548\right.$, $P=0,0014)$. In einigen Literaturstellen wird darauf hingewiesen, dass die Anzahl an Ausflügen pro Zelle durch indirekte Parameter möglicherweise 
nicht korrekt zu ermitteln ist. Die Vor- und Nachteile einiger Methoden zur Erfassung der Ausflüge pro Zelle werden diskutiert.

Vergleicht man Arten untereinander, so sind die Sammelausflüge/Stunde nicht mit der Körpergröße korreliert. Entsprechend sind Ausflüge/Stunde und Pollenladung berechnet als Prozent des Körpergewichtes nicht korreliert, weder auf der Basis des Frischgewichtes $\left(\mathrm{R}^{2}=0,009, P=0,811\right)$ noch des Trockengewichtes $\left(\mathrm{R}^{2}=0,107, P=0,201\right)$. Die Versorgungsraten ( $\%$ des gesammelten Körpergewichtes der Sammlerin pro Stunde) liegen zwischen 26,7 und 504,0\%/Stunde.

Geringe Versorgungsraten bedeuten eine geringe Anzahl an Zellen pro Tag (oft $<1$ ). Allerdings versorgen einige Bienen mit hohen Versorgungsraten auch nicht mehr als eine Zelle pro Tag, was bedeuten könnte, dass bei diesen Arten die Reproduktionsrate durch das Fehlen reifer Eier begrenzt wird. Unter optimalen Bedingungen können einzelne Bienen bis zu 9 Zellen pro Tag versorgen, doch sind solche Raten nicht auf Dauer aufrecht zu erhalten. Es erscheint unwahrscheinlich, dass irgendeine Art durchschnittlich mehr als 3 Zellen pro Tag versorgt, in den meisten Fällen dürften es eine oder weniger pro Tag sein.

Die Daten zum Versorgungsverhalten sind weit verstreut und unvollständig. Nur wenige Arten sind im Detail untersucht und Vergleiche sind oft schwierig, da Parameter wie Körpergewichte, Versorgungsgewichte oder Gewichte der Pollenladungen fehlen. Die Beziehung von Versorgungsraten zur Verfügbarkeit von Ressourcen ist weitgehend unbekannt und erfordert weitere Untersuchungen.

\section{Versorgungsrate / Körpergröße / Transportka- pazität / Solitärbienen / Ausflugsdauer}

\section{REFERENCES}

Aguiar C.M.L., Gaglionne M.C. (2003) Nesting biology of Centris (Centris) aenea Lepeletier (Hymenoptera, Apidae, Centridini), Rev. Bras. Zool. 20, 601-606.

Alcock J. (1999) The nesting behavior of Dawson's burrowing bee, Amegilla dawsoni (Hymenoptera: Anthophorini), and the production of offspring of different sizes, J. Insect Behav. 12, 363-384.

Baker H.G., Baker I. (1979) Starch in angiosperm pollen grains and its evolutionary significance, Am. J. Bot. 66, 591-600.

Batra S.W.T., Norden B.B. (1996) Fatty food for their brood: how Anthophora bees make and provision their cells (Hymenoptera: Apoidea), Mem. Entomol. Soc. Wash. 17, 36-44.

Bischoff I., Kerstein F., Breckner D. (2003) Foraging strategy and pollen preferences of Andrena vaga (Panzer) and Colletes cunicularius (L.) (Hymenoptera), J. Hymenopt. Res. 12, 220-237.
Bohart G.E., Youssef N.N. (1976) The biology and behavior of Evylaeus galpinsiae Cockerell (Hymenoptera: Halictidae), Wasmann J. Biol. 34, 185-234.

Boomsma J.J. (1989) Sex investment ratios in ants: has female bias been systematically overestimated? Am. Nat. 133, 517-532.

Boomsma J.J., Eickwort G.C. (1993) Colony structure, provisioning and sex allocation in the sweat bee Halictus ligatus (Hymenoptera: Halictidae), Biol. J. Linn. Soc. 48, 355-377.

Bosch J., Vicens N. (2002) Body size as an estimator of production costs in a solitary bee, Ecol. Entomol. 27, 129-137.

Bullock S.H. (1999) Relationships between body size, wing size and mass in bees from a Tropical Dry Forest in Mexico, J. Kans. Entomol. Soc. 72, 426439.

Cameron S.A., Whitfield J.B., Hulsander C.L., Cresko W.A. (1996) Nesting biology and foraging patterns of the solitary bee Melissodes rustica (Hymenoptera: Apidae) in Northwest Arkansas, J. Kans. Entomol. Soc. 69 Suppl., 260-273.

Cameron S.A., Ramirez S. (2001) Nest architecture and nesting ecology of the orchid bee Eulaema meriana (Hymenoptera: Apinae: Euglossini), J. Kans. Entomol. Soc. 74, 142-165.

Camillo E. (2005) Nesting biology of four Tetrapedia species in trap-nests (Hymenoptera: Apidae: Tetrapdediini), Rev. Biol. Trop. 53, 175-186.

Cane J.H., Schiffhauer D., Kervin L.J. (1996) Pollination, foraging and nesting ecology of the leaf-cutting bee Megachile (Delomegachile) addenda (Hymenoptera: Megachilidae) on cranberry beds, Ann. Entomol. Soc. Am. 89, 361-367.

Danforth B.N. (1989a) Nesting behavior of four species of Perdita (Hymenoptera: Andrenidae), J. Kans. Entomol. Soc. 62, 59-79.

Danforth B.N. (1989b) The evolution of hymenopteran wings: the importance of size, J. Zool., Lond. 218, 247-276.

Danforth B.N. (1990) Provisioning behavior and the estimation of investment ratios in a solitary bee, Calliopsis (Hypomacrotera) persimilis (Cockerell) (Hymenoptera: Andrenidae), Behav. Ecol. Sociobiol. 27, 159-168.

Danforth B.N. (1991) Female foraging and intranest behavior of a communal bee, Perdita portalis (Hymenoptera: Andrenidae), Ann. Entomol. Soc. Am. 84, 537-548.

Frohlich D.R., Parker F.D. (1983) Nest building behavior and development of the sunflower leafcutter bee: Eumegachile (Sayapis) pugnata (Say) (Hymenoptera: Megachilidae), Psyche 90, 193-209.

Gebhardt M., Röhr G. (1987) Zur Bionomie der Sandbienen Andrena clarkella (Kirby), A. cineraria (L.), A. fuscipes (Kirby) und ihrer Kuckucksbienen (Hymenoptera: Apoidea), Drosera 87, 89-114. 
Giovanetti M., Lasso E. (2005) Body size, loading capacity and rate of reproduction in the communal bee Andrena agilissima (Hymenoptera: Andrenidae), Apidologie 36, 439-447.

Goodell K. (2003) Food availability affects Osmia pumila (Hymenoptera: Megachilidae) foraging, reproduction, and brood parasitism, Oecologia $134,518-427$.

Janjic J., Packer L. (2001) New descriptions of Halictus (Seladonia) from the New World (Hymenoptera: Halictidae), J. Hymenopt. Res. 10, 55-75.

Johnson M.D. (1988) The relationship of provision weight to adult weight and sex ratio in the solitary bee, Ceratina calcarata, Ecol. Entomol. 13, $165-170$.

Kim J.-Y. (1999) Influence of resource level on maternal investment in a leaf-cutter bee (Hymenoptera: Megachilidae), Behav. Ecol. 10, 552-556.

Klostermeyer E.C., Mech S.J. Jr, Rasmussen W.B. (1973) Sex and weight of Megachile rotundata (Hymenoptera, Megachilidae) progeny associated with provision weights), J. Kans. Entomol. Soc. 46, 536-548.

Kuhlmann M. (2006) Scopa reduction and pollen collecting of bees of the Colletes fasciatusgroup in the winter rainfall area of South Africa (Hymenoptera: Colletidae), J. Kans. Entomol. Soc. 79, 165-173.

Levin M.D. (1966) Biological notes on Osmia lignaria and Osmia californica (Hymenoptera: Apoidea, Megachilidae), J. Kans. Entomol. Soc. 39, 523535.

Minckley R.L., Wcislo W.T., Yanega D., Buchmann S.L. (1994) Behavior and phenology of a specialist bee (Dieunomia triangulifera) and sunflower (Helianthus) pollen availability, Ecology 75, 1406-1419.

Mohamed M.I. (1973) A new method for determining the number of journeys needed by solitary bees to provision a cell, Bull. Soc. Entomol. Egypte 57, $435-440$.

Neff J.L. (2003) Nest and provisioning biology of the bee Panurginus polytrichus Cockerell (Hymenoptera: Andrenidae), with a description of new Holcopasites species (Hymenoptera: Apidae), its probable nest parasite, J. Kans. Entomol. Soc. 76, 203-216.

Neff J.L., Danforth B.N. (1991) The nesting and foraging behavior of Perdita texana (Cresson) (Hymenoptera: Andrenidae), J. Kans. Entomol. Soc. 64, 394-405.

Neff J.L., Simpson B.B. (1992) Partial bivoltinism in a ground-nesting bee: the biology of Diadasia rinconis in Texas (Hymenoptera, Anthophoridae), J. Kans. Entomol. Soc. 65, 377-392.

Neff J.L., Simpson B.B. (1997) Nesting and foraging behavior of Andrena (Callandrena) rudbeckiae Robertson (Hymenoptera: Apoidea: Andrenidae) in Texas), J. Kans. Entomol. Soc. 70, 100-113.
Neff J.L., Simpson B.B., Dorr L.J. (1982) The nesting biology of Diadasia afflicta Cresson (Hymenoptera: Anthophoridae), J. Kans. Entomol. Soc. $55,499-518$.

Norden B., Batra S., Fales H., Hefetz A., Shaw, G. (1980) Anthophora bees: unusual gylcerides from maternal Dufour's glands serve as larval food and cell lining, Science 207, 1095-1097.

Ordway E. (1984) Aspects of the nesting behavior and nest structure of Diadasia opuntiae Ckll, (Hymenoptera: Anthophoridae), J. Kans. Entomol. Soc. 57, 216-230.

Parker F.D., Tepedino V.J., Bohart G.E. (1981) Notes on the biology of a common sunflower bee, Melissodes (Eumelissodes) agilis Cresson, J. N.Y. Entomol. Soc. 89, 32-52.

Phillips J.K., Klostermeyer E.C. (1978) Nesting behavior of Osmia lignaria propinqua (Hymenoptera: Megachilidae), J. Kans. Entomol. Soc. 51, 91-108.

Roulston T.H., Cane J.H. (2000) Pollen nutritional content and digestibility for animals, Plant Syst. Evol. 222, 187-209.

Roulston T.H., Cane J.H. (2002) The effect of pollen protein concentration on body size in the sweat bee Lasioglossum zephyrum (Hymenoptera: Apiformes), Evol. Ecol. 16, 49-65.

Roulston T., Cane J.H., Buchmann S.L. (2000) What governs protein content of pollen: pollinator preferences, pollen-pistil interactions, or phylogeny, Ecol. Monogr. 70, 617-634.

Rozen J.G. Jr. (1984) Nesting biology of diphaglossine bees (Hymenoptera, Colletidae), Am. Mus. Novit. 2786, 1-33.

Rust R.W. (1980) The biology of Ptilothrix bombiformis (Hymenoptera: Anthophoridae), J. Kans. Entomol. Soc. 53, 427-436.

Rust R.W., Thorp R.W., Torchio P.F. (1974) The ecology of Osmia nigrifrons with a comparison to other Acanthosmoides, J. Nat. Hist. 8, 29-47.

Sipes S.D., Wolf P.G. (2001) Phylogenetic relationships within Diadasia, a group of specialist bees, Mol. Phylogenet. Evol. 19, 144-156.

Stone G.N. (1994) Activity patterns of females of the solitary bee, Anthophora plumipes in relation to temperature, nectar supplies and body size, Ecol. Entomol. 19, 177-189.

Strickler K.S. (1979) Specialization and foraging efficiency of solitary bees, Ecology 60, 998-1009.

Strickler K.S. (1982) Parental investment per offspring by a specialist bee: does it change seasonally? Evolution 36, 1098-1100.

Sugiura N., Maeta Y. (1989) Parental investment and offspring sex ratio in a solitary mason bee, Osmia cornifrons (Radoszkowski) (Hymenoptera, Megachilidae), Jpn J. Entomol. 57, 861-875.

Tepedino V.J., Torchio P.F. (1982) Phenotypic variability in nesting success among Osmia lignaria propinqua females in a glasshouse environment 
(Hymenoptera: Megachilidae), Ecol. Entomol. 7, 453-462.

Tomkins J.L., Simmons L.W., Alcock J. (2001) Brood provisioning strategies in Dawson's burrowing bee, Amegilla dawsoni (Hymenoptera: Anthophorini), Behav. Ecol. Sociobiol. 50, 81-89.

Todd F.E., Bretherick O. (1942) The composition of pollens, J. Econ. Entomol. 35, 312-317.

Torchio P.F. (1989) In-nest biologies and development of immature stages of three Osmia species (Hymenoptera, Megachilidae), Ann. Entomol. Soc. Am. 82, 599-615.

Trivers R.L., Hare H. (1976) Haplodiploidy and the evolution of the social insects, Science 191, 249-263.

Vinson S.B., Frankie G.W. (1999) Nesting behavior of Centris flavofasciata (Hymenoptera: Apidae) with respect to the source of the cell wall, J. Kans. Entomol. Soc. 71, 46-59.

Visscher P.K., Danforth B.N. (1993) Biology of Calliopsis pugionis (Hymenoptera: Andrenidae): nesting, foraging, and investment sex ratio, Ann. Entomol. Soc. Am. 86, 822-832.

Wcislo W.T., Wille A., Orozco E. (1993) Nesting biology of tropical solitary and social sweat bees, Lasioglossum (Dialictus) figueresi Wcislo and $L$. (D.) aeneiventre Friese (Hymenoptera: Halictidae), Insectes Soc. 40, 21-40.

Witt R. (1992) Zur Bionomie der Sandbiene Andrena barbilabris (Kirby 1802) and ihrer Kuckucksbienen Nomada alboguttata HerrichSchäffer 1893 und Sphecodes pellucidus Smith 1845, Drosera 92, 47-81. 